\title{
NEW MEDIA PRACTICES IN IRAN: A MIXED METHODS STUDY
}

\author{
Sefer KALAMAN \\ Bozok University, Turkey \\ https://orcid.org/0000-0002-2761-1229 \\ sefer.kalaman@bozok.edu.tr
}

\begin{abstract}
The aim of the study is to reveal the current state of Iran, which has more different structures than other countries in terms of political, social and cultural, in the new media area. In the study, a mixed methods research was conducted to reveal the existing situation and the mixed methods convergent parallel design was used in the research. The interview method, one of the qualitative research methods and the survey, one of the quantitative reasrch methods were used in the research. The sample of the interview method is a senior official at the Ankara Embassy of Iran, who is selected by means of purposive sampling. The sample of the survey is 124 Iranian people, who are selected by means of purposive sampling method. According to the results obtained from the analysis of research data, there are some restrictions in the new media environment in Iran, but most of the internet sites and social networks can be accessible is in general. Restrictions of the Internet and new media in Iran are being implemented because of the ethical reasons, insecurity about foreign countries and the willingness of the country's government to prevent or control opponents. Despite partial restrictions, most of the Iranian population access the internet and highly use the platforms of this virtual network.
\end{abstract}

Keywords: New Media, Iran, Qualitative Research, Quantitative Research, Mixed Methods Research

\section{IIRAN'DA YENI MEDYA UYGULAMALARI: BİR KARMA YÖNTEM ÇALIŞMASI}

\section{ÖZ}

Çalışmada, siyasal, sosyal ve kültürel açıdan diğer ülkelere nazaran farklı bir yapıya sahip olan İran'ın, yeni medya alanındaki mevcut durumunu ortaya koymak amaçlanmıştır. Çalışmada, var olan durumu ortaya çıkarmak için bir karma yöntem araştırması yapılmış ve araştırmada yakınsayan paralel karma yöntem deseni kullanılmıştır. Araştırmada, nitel araştırma yöntemlerinden biri olan görüşme yöntemi ve nicel araştırma yöntemlerinden biri olan anket yöntemi kullanılmıştır. Görüşme yönteminde örneklemi, amaçlı örnekleme yöntemiyle seçilen İran'ın Ankara Büyükelçiliği'ndeki üst düzey bir yetkili oluşturmaktadır. Anket yönteminde ise örneklemi, amaçlı örnekleme yöntemi ile seçilen 124 İranlı kişi oluşturmaktadır. Araştırma verilerinin analizinden elde edilen sonuçlara göre, İran'da yeni medya ortamında bir takım kısitlamalar mevcuttur ancak genel olarak internet siteleri ve sosyal paylaşım ağlarının çoğuna erişim sağlanmaktadır. İran'daki internet ve yeni medya alanındaki kısıtlamalar, ahlaki sebeplerden, yabancı ülkelere duyulan güvensizlikten ve ülke yönetiminin muhalifleri engellemek ya da kontrol altına almak istemesinden dolayı uygulanmaktadır. Kısmi olarak gerçekleşen kısıtlamalara rağmen İran halkının çok büyük bir kısmı internete erişmekte ve bu sanal ağdaki platformları yüksek oranda kullanmaktadır.

Anahtar Kelimeler: Yeni Medya, Iran, Nitel Araştırma, Nicel Araştırma, Karma Yöntem Araştırması

\section{INTRODUCTION}

In every century of world history some social, political, economic or technological events or developments, which have influenced that period, have emerged. The invention of wheels, the 
invention of writing and paper, the first and second world wars, the invention of newspapers, radio, cinema and television, the design of microchips and the invention of the internet constitute a few of the most important of these relevant developments.

The qualities of the Internet in terms of these developments are separated from other developments at few points. The Internet incorporates the most technologically advanced applications than in all previous developments. Apart from this, Internet has a feature that influences the countries of the world in terms of socio-cultural, political, economic and technological developments and overshadows other developments and innovations.

Serving the creation of a new world order and the gathering of all cultures and human activities under an umbrella, the internet now means that integrate the human lifestyle into the world regardless of the cultural needs of the nation and the specific conditions (Kashani et al., 2017: 235).

This virtual network, which is used by billions of people, has changed the countries as well as the people, cultures and habits and has adapted them to itself. In fact, countries like China, North Korea and Iran, which are considered as closed societies or closed countries in the world, have not been unconcerned to the influence of the internet. People in these countries like people in other countries; want to use this digital network extensively to meet their needs such as socialization, reaching news, interacting, shopping, entertainment, research and information. So, this resulted in the fact that these relevant countries do not ignore the Internet and totally prohibit it.

The Internet, which is seen as an area of unlimited freedom, differs from country to country at the points of usage and practice. The potential of the Internet, impact, size, the advantages and disadvantages it creates causes countries to implement some practices, measures or constraints on this virtual platform. The United States closes these sites on the internet to block child pornography. The People's Republic of China censors to Internet sites to block people who are opposed to the party, and thus the state, and punish those who violate it. Iran, on the other hand, may have restrictions or censorship to Internet because of moral reasons, distrust of foreign countries, and the willingness of the country's government to block or control opponents.

Although each country imposes restrictions or censorship on the internet for different reasons, the restrictions of some closed societies or countries may be seen different in the external world. Middle Eastern countries or underdeveloped countries are usually exposed to such negative situations. One of these negative stereotypes, which is especially created by western countries in many fields, is the new media practices of Iran. There are many news, articles, books, etc., which are created in the different countries of the world especially in West in terms of orientalist point of view argues that Iran has completely forbade the new media environment, Iranian people can not use social networks and there is a total violation of freedom.

From this point of view, it is aimed to introduce the current condition of internet and new media in Iran. In the scope of the study, the level of internet and new media usage in Iran, used and unused social networks, the aims of the people to use these social networks, the aim of the people to use this virtual network, whether there are any censorship to internet or new media, if so why the censorship and restriction is applied, whether the applied restrictions are overcome and whether there is a criminal sanction in the case of exceed of the restriction are studied.

\section{New Media Practices in Iran}

The communication policies of the countries are directly related to the general policy conception of those countries. For this reason, it is necessary to recognize the political and economic system of the country before defining communication policies. The state structure of Iran is regarded as a unique system with its own characteristics. When the political practices in the country are examined, Iran can not be explained as a country neither a full republic, to be directed to Islamic religion, to be suitable for the rule of the sultanate, to be depended on monarchy system nor totalitarian regime (Kamaladdin, 
2017: 54). This complicated structure of the Islamic Republic of Iran has become more grift, especially to the results of the political and social transformations in recent years. The political structure during the Pahlavi period leaves its place in a new political power with the realization of revolutions, which changes the face of the country completely.

Iran made important strides in the name of modernization by earning good economic income in the Pahlavi Period and adopting Western culture. Muhammad Riza Pahlavi, who came to the throne in 1941, made some attempts to make Iran a western-oriented and secular country with hard methods. The imposed social and economic lifestyle by Pahlavi to Iranian people, which stems from American, caused some dissatisfaction within the people. In the course of time, the interference of the America to the Iran's internal affairs, the economic politics gap between the classes, and the deviation from the values that Iran possesses were resulted in the unification of people and groups with different views. These people and groups united against the regime and in 1979 the Iranian revolution under the leadership of Ruhullah Khomeini was realized. Revolution leader Ruhullah Khomeini proclaimed a new political structure and founded the Islamic Republic of Iran. This historical event, which was carried out against the regime and soon turned into an Islamic revolution, caused Iran to enter a new turn.

Unlike the Pahlavi period, the Islamic Republic of Iran has always adopted an anti-Western attitude. This way of thinking took also place in the governing of the country. The "Cultural War" discourse, which was widely used in the 1990s, is a clear example of this ideology. The discourse of cultural warfare is widely used by particularly the head of the religious leaders and all responsible, religious leaders, and the media in Iran. At that time, through the propaganda tools of the state, which were related to the cultural war, many messages were sent to the citizens every day through news, speeches, interviews. (Kamaladdin, 2017: 55-57). Ministry of Information and Communication Technologies officials and other government officials warned the public against "the dangers of foreign services" at every turn (Anderson, 2012: 2).

This politicy of the state has also manifests itself in the media field and begins controlling the media in order to dominate its power and overcome a western-oriented cultural war or in other words it subjects to a rigorous control. The state guarantees this power with the 175th article of the Constitution with the law. According to $175^{\text {th }}$ Article of the Constitution of the Islamic Republic of Iran (iranonline, 2017), The freedom of expression and dissemination of thoughts in the Radio and Television of the Islamic Republic of Iran must be guaranteed in keeping with the Islamic criteria and the best interests of the country. The appointment and dismissal of the head of the Radio and Television of the Islamic Republic of Iran rests with the Leader. A council consisting of two representatives each of the President, the head of the judiciary branch and the Islamic Consultative Assembly shall supervise the functioning of this organization. The policies and the manner of managing the organization and its supervision will be determined by law.

Apart from communication platforms such as radio, television, and newspapers, the Internet has been subjected to this control. Internet usage in Iran was supported by the government for the first time to provide an alternative means of scientific and technological progress during the troubled economic period following the Iran-Iraq War. Unlike the anticipations of that time, the Islamic Republic welcomed the internet by enabling the commercial and educational sectors to gain access without intervention. While technology in China was developed by the government as a large-scale intragovernment network, Iran's first usage of the Internet took place in 1993 at the Center for Physics Research, which is affiliated to Tehran University, and then the Internet began to spread country-wide. The internet has become an important tool for interacting with other countries in the world with an increasing demand for film industry and satellite dishes on the international arena (Rahimi, 2003: 102104) and this interaction has caused many changes in the societyof Iran. In those years, the Iranian people, who are exposed to political restrictions in different areas of life, have started to carry out many activities such as communication, entertainment and forming a community through this virtual network. 
The internet technology in Iran caused the opposing movements to become significantly stronger with the interactivity they have, the quick and easy access to the news and the ability to produce content and free communication (Grossman, 2009; Michaelsen, 2011: 105). The opposing party in Iran greatly benefited from the Internet to communicate, organize and announce their voices among themselves, and established many sites to accomplish these goals (Mostafalou and Adnan, 2016: 123). The Iranian Green Movement, which is a social movement that took place in 2009 by including millions of Iranians, constitutes one of the most important developments that reveal the importance and power of the Internet.

Although the Internet began to be used by the public at a high level in those years, it did not meet expectations in terms of speed. In addition to the low speed of the Internet, the closure of many Internet sites limited the mobility of internet users in Iran in this virtual network and caused their freedom to be restricted. There are many moral, political and social reasons for the restrictions or censorship in the internet field in the country. The Iranian authorities put forward the moral causes in response to the criticism directed at them about the restriction or censorship of the Internet. Current restrictions, filters or censors of the internet in the country vary depending on the content or the quality of the site. From a general perspective, censorship is very important in some fiels in Iran, while in some fields there is no or very little censorship.

In the study of Aryan and his colleagues (2013: 3) on internet censorship in Iran, 500 websites in the country were examined and it was determined that the most exposed sites were the sites, which have sexual content. At the end of the analysis it is shown that the websites with the theme of Art, Top 500 and Society has almost half censorship rate, but in the websites with the theme of News, Regional, Computers, Games, Shopping, Sports, Kids \& Teens, Business, Recreation, Home, Health, Iran, Science and Reference the censorship rate on internet is very low.

According to the laws of the Islamic Republic of Iran, membership in social network sites like Facebook and Twitter is not a crime. However, because of having filters on the vwebsites like Facebook and Twitter, it is possible for citizens to access these websites via proxy programs. Despite these restrictions, names like Religious Leader Hameney, Hashimi Rafsanjani and the new government minister of foreign affairs called Muhammed Javad Zarif have accounts on Facebook, as well as the new president Ruhani and Muhammad Javad Zarif, have also accounts on Twitter (Kamaladdin, 2017: 62). Prohibition of using a proxy in the country doesn't mean that people don't use this program. On the contrary, most of the users in the country access to almost all internet sites and social networks, and they access to the limited sites and networks through the programs they use.

Although the restrictions, slowdowns and censorship activities, which were carried out in Iran in the previous years, affected the access of the people to the internet negatively, the interest of the people to the internet was not decreased and the internet usage rate of the Iranian people continued to increase day by day. All in all, only $15.9 \%$ of Iranian population used internet in 2010 according to the data of Worldbank (2016), while in 2016, 53.2\% of Iranian population used internet. According to the report of the International Telecommunication Union (2017: 139-143), by year of 2016, 62.2\% of houses in Iran have internet connection and $53.2 \%$ of Iranian people use internet. According to data of Wearesocial (2017: 62), the number of Internet users in Iran, which has a population of 80 million by 2017, has increased $21 \%$ to reach 57 million. There are also 17 million active social media users in the country.

The fact that the citizens in the country, especially young people, are very active in the virtual environment and use the internet intensely has caused the government to soften their internet applications (Kamaladdin, 2017: 58). According to the results of the research conducted in Iran, 90.3\% of the young people, who participates in the survey, have internet-related smartphones and the young people are connected to the internet via different methods (Ghasemi et al., 2017: 876).

The Internet, which is widely used in Iran and spread to the general public, is in a better position than most countries in the world in terms of price and speed. Iran is the country where the cheapest internet in the world is used with 5.37 USD at the internet usage fee point. The internet speed in the country 
has increased by 4.7 Mbps in 2017 (Cable, 2017; Tradingeconomics, 2017) even though it was very low in the past years. It is possible to say that the prevalence of internet usage in Iran, the cheapness of the internet, the interest of the people on the internet, and the increasing internet infrastructure will cause the change of Iran, which is regarded as closed and restrictive, and increase the freedom in Iran day by day.

A research was carried out using a mixed methods research technique including qualitative and quantitative methods to reveal the current situation of internet and new media usage of Iran, which is separated from other countires in terms of its characteristics, and to support the theoretical part obtained. The study includes the data obtained from the research and the results of the analysis.

\section{Methods}

Within the years of Academic world; (Creswell and Clark, 2015: 3) a variety of mixed methodologies, which include various components of methods, research processes, philosophy and research designs, have emerged. Mixed methods research is the third method of research after quantitative and qualitative research methods.

According to Johnson and his colleagues (2007), a mixed methods research is a kind of research in which a researcher or research team combines the components of qualitative and quantitative research approaches (etc, qualitative and quantitative perspectives, use of data collection, analysis and inferential techniques) for the broadness and depth of understanding and confirmation. In other words, mixed methods research means that a scientific research is carried out using both qualitative and quantitative methods.

In the study, a mixed methods research was conducted, which includes a semistructured interview technique, a qualitative method and a survey, quantitative method. While the designing of the research "convergent parallel design", which is one of the mixed methods designs was chosen. In the convergent parallel design, the researcher carries out the qualitative and quantitative research process together and gives equal priority to both methods. In the convergent parallel design, the data are solved separately and then combine with the results in the general interpretation stage.

\section{Semistructured Interview}

In the study, a survey was conducted to identify new media applications in Iran. A semistructured interview technique, which is one of the qualitative research methods, was used in the research. The universe of the study is the new media users in Iran, while the sample is a senior official in Iran's Ankara Embassy. The purposive sampling method was used when determining the sampling.

There are totally 7 questions in the semistructured interview form created by the researchers. The interview was held on 08.12.2017 and recorded with the authorized voice recording device in the Embassy of Iran in Ankara. For security reasons, the name of the person participating in the interview is kept secret.

The participant, who is an expert in the field of communication and new media were asked a number of questions and got answers about new media applications in Iran.

Question 1. Can you tell us about the media structure in Iran and Iran's view of the Turkish media?

Answer 1. "In Iran, the media mainly broadcast in Persian and English. Turkish broadcast is also limited. IRNA, FARS, DESINIM and MEHR news agencies are mainly active. These agencies are also broadcasting in Turkish. But there are also weak points of Turkey. There is a $\$ 12$ billion trade volume between Turkey and Iran. But there is a weak communication between Iran and Turkish press. There is only a small amount of Persian news in the Anatolian Agency and TRT. These are generally negative news. They do not have a network, which includes all the news... 
I may have a suggestion to solve this problem; For example, CNN Turk, the institution you work for, can hire an Iranian student. This person will translate Iranian news from Persian to Turkish and you can have a broader news network of our country. Again important broadcast organs such as CNN Turk, NTV and Star can broadcast in Persian ..."

Question 2. What are the new media platforms (blogs, internet sites, social networks) used in Iran?

Answer 2. "The Telegram is being used a lot. There are over 20 million users. WhatsApp is in use. LINE is used. IMO is used. Facebook, FaceTime and Twitter are used."

Question 3. What does the new media mean for the government of Iran?

Answer 3. "There is not only the personal sharing of the citizens in the media. A lot of information and news can also be shared. It became possible to hear and share immediately when there is an event anywhere in the world. In Iran, the motives of the people are in front of the government's motives. No news is possible to hide. For example, I can take your photo right now (he had already took my photo while I was taking notes). I can do this top news on my telegram page. Anyone who follows my page in Iran can see it.

The role of social media is huge. States are using it against both inside and outside. We saw how effective such practices during the coup attempt on July, the $15^{\text {th }}$. President Recep Tayyip Erdogan linked to Hande Firat from CNN Turk through FaceTime. He has spoken to the nation from there... The cost of the fighting via Instagram and WhatsApp - I say openly - cost 1 lira. That's the internet money.

We will give another example about the effects of the new media. For example, you committed a crime. This was taken by the state's mobese and the state learned. Now you will be punished, but nobody knows it. But if you are papped by social media cameras, even if you are innocent, you can be seen different and you will have run of bad luck. Thus, it may be a very dangerous device.

Social media is not beneficial because it was not produced by the users of Turkey, Iran or 3rd world countries. But there are also good advantages ..."

Question 4. There is a perception that Iran is looking at new media elements and social networks from a "forbidding" point of view. What do you say about this perception? Do you forbid social media?

Answer 4. "The prohibition of social networks is related to moral situations. Some of them are releasing the morality of society by broadcasting porn movies. These sections are filtered, and the remaining sections are still in use. There are young people aged 14-15. Their moral code has not yet been shaped. You can mislead them in these ways. You are also a Muslim country. If the moral rules are disregarded, the result will be heavy. Besides, some networks are banned in Turkey. We have to protect social security and social morals.

Question 5. Are there any banned networks now? For example, Twitter?

Answer 5. "Twitter is not forbidden. All applications such as WhatsApp, LINE, IMO, Facebook, FaceTime and Telegram are used."

Question 6. Where does the problem stem from? Because of the servers of these websites located abroad? As far as I know you have requests to be brought to Iran...

Answer 6. "All of their servers are abroad. If the servers are in our country, users will be able to reach it faster. As every country wants, we also want the servers to be in our country. Most of them are connected to the CIA (United States - Central Intelligence Agency). They share information with intelligence services. It's a source of intelligence. We do not have any worry. Our country is open and democratic. There is nothing to hide ... But the people are not fully aware of the danger and the threats. We have to protect them as a state. We have enemies like that, they turn the things upside down, and all these countries hold power of the press" 
Question 7. Are the prohibitions and filters imposed by the state broken? How does the public meet these filters?

Answer 7. "Developing technology makes it easy to break the filters. People benefit from it. Similar initiatives are also taking place in European countries. It is important to protect the morality of the community. Our people are revolutionary people. They revolutionized and built a system and voted. Almost every year there is an election in our country; such as the Assembly election, the City Council election, the Presidential election. People elect their institutions. Everything is done by the votes of the people. Therefore, tlaws are determined by majority in Iran. Of course, men are not all like. Some are tall and some are short. There may be opponents. But after the law put into force, everybody has to comply."

\section{Survey}

In the study, a survey, which is one of the quantitative research methods, was conducted in order to determine the new media practices in Iran. While the universe of work constitutes the new media users in Iran, the sample is composed of 124 Iranian people selected by the purposive sampling method.

There are totally 18 questions are included in the survey form prepared by the researchers. The data obtained from the survey, which was conducted on November of 2017, was analyzed through the program called SPSS. In terms of the reliability of the study, the data were subjected to the Cronbach's Alpha test and the result was found to be reliable according to the value obtained $(0,633)$. During the process of prepairing, the survey questions, which are considered to be realible by the data obtained from Cronbach's Alpha Test, preapered working together with a specialist academics group in order to understand whether the content was carrying out the research objectives and it is determined that the content of the survey is valid.

When the demographic information of the participants included in the survey were examined, it is found that $55,6 \%$ of the participants were female, $77,5 \%$ of the participants were in the age range of $15-39,74,2 \%$ of them had a bachelor degree and above and $57,2 \%$ of them are a fee- earner or a student.

When the internet and new media usage practices of the participants were examined, $54,8 \%$ of the participants use internet and new media at least 4 hours a day, $91,9 \%$ of them are connected to internet and new media by mobile phone, $56,5 \%$ of them use internet to enter social networking sites, $54,8 \%$ of them use at least 3 social networks, and $96,8 \%$ of them mostly use the social network called Telegram (Table 1).

Table 1. Internet and New Media Usage

\begin{tabular}{|c|c|c|c|}
\hline & Categories & Number & $\%$ \\
\hline \multirow[t]{6}{*}{ Internet and new media usage time } & Less than 1 hour & 10 & 8,1 \\
\hline & $1-3$ hours & 46 & 37,1 \\
\hline & 4-6 hours & 26 & 21,0 \\
\hline & 7-9 hours & 22 & 17,7 \\
\hline & More than 9 hour & 20 & 16,1 \\
\hline & Total & 124 & 100 \\
\hline \multirow[t]{3}{*}{ Connecting from a mobile phone } & Yes & 114 & 91,9 \\
\hline & No & 10 & 8,1 \\
\hline & Total & 124 & 100 \\
\hline \multirow[t]{6}{*}{ Purpose of internet usage } & Social media & 70 & 56,5 \\
\hline & Research and information & 35 & 28,2 \\
\hline & Surf on internet & 12 & 9,7 \\
\hline & Play games & 3 & 2,4 \\
\hline & Other & 4 & 3,2 \\
\hline & Total & 124 & 100 \\
\hline \multirow[t]{3}{*}{ Number of social networks used } & 1 & 23 & 18,5 \\
\hline & 2 & 33 & 26,7 \\
\hline & 3 & 30 & 24,2 \\
\hline
\end{tabular}

Submit Date: 11.04.2018, Acceptance Date: 21.06.2018, DOI NO: 10.7456/10803100/012 


\begin{tabular}{|l|l|l|l|}
\hline \multirow{5}{*}{ Social networks used } & 4 & 16 & 12,9 \\
\cline { 2 - 4 } & More than 4 & 22 & 17,7 \\
\cline { 2 - 4 } & Total & 124 & 100 \\
\cline { 2 - 4 } & Telegram & 120 & 96,8 \\
\cline { 2 - 4 } & Twitter & 13 & 10,5 \\
\cline { 2 - 4 } & Facebook & 27 & 21,8 \\
\cline { 2 - 4 } & LINE & 15 & 12,1 \\
\cline { 2 - 4 } & IMO & 31 & 25,0 \\
\cline { 2 - 4 } & FaceTime & 7 & 5,6 \\
\cline { 2 - 4 } & WhatsApp & 27 & 21,8 \\
\cline { 2 - 4 } & Other & 32 & 25,8 \\
\hline
\end{tabular}

When the participants' opinions on internet and new media bans in Iran are examined, $90,2 \%$ of the participants have a partial access to social networks in Iran and only ne networks called Twitter and Facebook have restrictions. According to $41,9 \%$ of participants, only some parts of the social networks are limited and according to the almost half of the participants $(44,4 \%)$ the main reasons of these prohibitions is moral issues. According to the question, which supports this situation, $49,2 \%$ of the participants says that the prohibitions are applied due to moral reasons, $38,7 \%$ of them think that their servers are located abroad, and $40,3 \%$ of them thins that these networks are used by foreign intelligence units. Apart from this, $100 \%$ of the participants use a program to break the internet restriction. According to $71,0 \%$ of the participants, there is a penal sanction to who does not comply with the Internet ban (Table 2).

Table 2. Bans in the New Media Area

\begin{tabular}{|c|c|c|c|}
\hline & Categories & Number & $\%$ \\
\hline \multirow[t]{4}{*}{ Extent of access ban } & No access to all networks & 6 & 4,8 \\
\hline & Any social network is not banned & 6 & 4,8 \\
\hline & Partly banned & 112 & 90,2 \\
\hline & Total & 124 & 100 \\
\hline \multirow{8}{*}{ Social networks that is forbidden Access } & Telegram & 4 & 3,2 \\
\hline & Twitter & 97 & 78,2 \\
\hline & Facebook & 105 & 84,7 \\
\hline & LINE & 5 & 4,0 \\
\hline & IMO & 3 & 2,4 \\
\hline & FaceTime & 4 & 3,2 \\
\hline & WhatsApp & 23 & 18,5 \\
\hline & Other & 19 & 15,3 \\
\hline \multirow[t]{6}{*}{ Access problem } & Page completely banned & 25 & 20,2 \\
\hline & Some sections banned & 52 & 41,9 \\
\hline & Low connection & 36 & 29,0 \\
\hline & No problem & 10 & 8,1 \\
\hline & Other & 1 & 0,8 \\
\hline & Total & 124 & 100 \\
\hline \multirow[t]{6}{*}{ The reason of the ban } & Moral Reasons & 55 & 44,4 \\
\hline & Servers are out of the country & 33 & 26,6 \\
\hline & Internet is not wanted to be used & 39 & 31,5 \\
\hline & Discomfort from sharing & 34 & 27,4 \\
\hline & I do not know & 17 & 13,7 \\
\hline & Other & 29 & 23,4 \\
\hline \multirow{5}{*}{ Are the bans due to moral reasons? } & Yes & 32 & 25,8 \\
\hline & No & 41 & 33,1 \\
\hline & Partly agree & 29 & 23,4 \\
\hline & No idea & 22 & 17,7 \\
\hline & Total & 124 & 100 \\
\hline \multirow[t]{5}{*}{ Is it a problem that the servers are out of Iran? } & Yes & 17 & 13,7 \\
\hline & No & 52 & 41,9 \\
\hline & Partly agree & 31 & 25,0 \\
\hline & No idea & 24 & 19,4 \\
\hline & Total & 124 & 100 \\
\hline
\end{tabular}




\begin{tabular}{|l|l|l|l|}
\hline \multirow{4}{*}{ Is the information taken from foreign countries? } & Yes & 31 & 25,0 \\
\cline { 2 - 4 } & No & 39 & 31,5 \\
\cline { 2 - 4 } & Partly agree & 19 & 15,3 \\
\cline { 2 - 4 } & No idea & 35 & 28,2 \\
\cline { 2 - 4 } & Total & 124 & 100 \\
\hline \multirow{5}{*}{ Can restrictions be overcome? } & Yes & 124 & 100 \\
\cline { 2 - 4 } & No & 0 & 0 \\
\cline { 2 - 4 } & Total & 36 & 100 \\
\hline \multirow{2}{*}{$\begin{array}{l}\text { Are there punishments if the prohibitions are } \\
\text { not followed? }\end{array}$} & Yes & 88 & 71,0 \\
\cline { 2 - 4 } & No & 124 & 100 \\
\cline { 2 - 4 } & Total & & 29,0 \\
\hline
\end{tabular}

\section{DISCUSSION AND CONCLUSION}

Daily life practices, economic system, political structure, culture and habits of society, social order and many other areas have been transformed with the introduction of the Internet technology and new media, which is one of the most important elements of the Internet. This digital technology or virtual network has forced the countries and people to be changed because of its features. While people enjoy many life activities and even their needs through this virtual network, countries and prinvcipals of the countries use this digital technology to maintain, strengthen and facilitate the present situation and make things easier. However, the internet and new media policies changes from country to country because of its potential, power, size, advantages and disadvantages. From this point of view, a study was carried out to reveal thepresent situation of internet and new media in Iran, which has an intricate and different structure at the point of using the management system and internet and new media. In the study a mixed methods research, which includes qualitative and quantitative research methods, was used in order to reveal the present situation of the country.

According to the data taken from the participants, who are participated in the survey and the information obtained from the literature, the usage rate of internet and new media is high in Iran. According to data taken from Wearesocial (2017: 62), the number of Internet users in Iran, which has a population of 80 million by 2017 , has reached about 57 million. There are also 17 million active social media users in the country. According to the data of the survey, $54,8 \%$ of the participants use internet and new media at least 4 hours a day and a most of them $(91,9 \%)$ are connected to the internet and new media by mobile phone. More than half of the participants use the internet and new media to enter socialt networks the most and again more than hal of them use at least 3 social networks.

According to the results taken from both qualitative and quantitative research, the new media environment in the country is a very important factor. Internet users in Iran use Telegram, Twitter, Facebook, LINE, IMO, FaceTime, WhatsApp and other social networks, but they mostly use the social network called Telegram. Most of these social networks are not restricted, but there are restrictions on Facebook and Twitter.

According to most of the participants $(90,2 \%)$, these social networks are not fully, but partially, restricted. In addition, the speed of internet connection in the country is low. Iran is the cheapest country used Internet in the world but, the internet speed with at $4.7 \mathrm{Mbps}$ is lower than the western countries. In addition to social networks in Iran, the state also imposes some censorship and restrictions on internet sites. These restrictions or censures can be implemented either as a closure of the existing site or as a filter to access the relevant site.

According to the information taken from interviews, surveys and other studies, moral causes are the most important reasons for the restrictions and censorship practices to the internet and new media in Iran. The government closes or restricts such sites and networks because they do not comply with ethical rules and include pornographic content. In the study of Aryan and his colleagues (2013: 3), over 500 websites in the country were examined and the most exposed sites were the sexually explicit sites for adults. 
The fact that the servers of the websites or social networks are located abroad is also seen as another reason for the restrictions and obstacles. According to the almost one third of participants, the reason for this is that the servers of the networks are located abroad. According to the data obtained from senior official of Iran, who is participated in the interview, Iran wants to have the servers in the country like every country. If the servers are in Iran, the users will have the opportunity to access Internet more quickly. These networks and foreign intelligence agencies are connected to each other. These networks share the information of users in Iran with the intelligence services.

These restrictions are also related to the "cultural war" rhetoric that Iran created in the 1990s. Iran is also restricting people's freedom and also restricts many sites and networks in order to prevent people in the country from consuming western-oriented, especially American-oriented films, music and other content. However, this attitude in the early of 1990s and the attitudes and freedom violations in recent years are not at the same scale. At that time, and even today, Iran also censors or restricts the internet and new media in order to control, monitor and restrict the opponents in the country. But the developing technology has caused the people to intensively use this virtual network with the desire to interact with other countries, and the need to repair Iran's existing profile, resulting in restrictions on internet and softening of obstacles. Thus, people in Iran are already using those networks with some applications even if sites or networks are banned or restricted.

According to the data taken from interviews and surveys, Internet users in Iran can access these limited and blocked off networks by using programs/applications such as Proxy at the point in accessing to the restricted networks abroad. In fact, all participants of the survey indicate that they use a program to overcome these restrictions and obstacles. There is no criminal sanction for the access to the restricted or blocked off networks. Most of the participants $(71,0 \%)$ agree this idea.

As a result, the use rate of internet and new media in Iran is high and it has dramatically increased. It is possible to access many networks and websites in the country, but some sites and networks are censored or restricted filtering, closing or blocking by the state. The public overcome these restrictions with different programs and so they access the networks they want. In the view of such informations and parallel to the increase in technological developments, it seems possible that Iran as a soft power will soften in the internet field and giving the freedom become compulsory in the following years.

\section{REFERENCES}

Anderson, C. (2012). The Hidden Internet of Iran: Private Address Allocations on a National Network. Cornell University Library, https://arxiv.org/abs/1209.6398, Access Date: 17.12.2017.

Aryan, S., Aryan, H., Halderman J. A. (2013). Internet Censorship in Iran: A First Look. Proceedings of the 3rd USENIX Workshop on Free and Open Communications on the Internet.

Cable (2017). Study of Broadband Pricing in 196 Countries Reveals Vast Global Disparities in the

Cost of Getting Online - UK Ranks 62nd Cheapest. https://www.cable.co.uk/mediacentre/release/new-worldwide-broadband-price-league-unveiled/, Access Date: 01.11.2017.

Creswell, J. W., Clark, V. L. P. (2015). Karma Yöntem Araştırmaları Tasarımı ve Yürütülmesi. Yüksel Dede ve Selçuk Beşir Demir (Çev.). Ankara: Anı Yayıncılık.

Ghasemi, V., Rabiei, K., Davoodi, S., Rabiei, H. (2017). Mobile Internet Usage among Adolescents and Young Adults in Iran: A Sociological Survey. Journal of History Culture and Art Research, Vol 6, No. 1, p. 863-878.

Grossman, L. (2009). Iran Protests: Twitter, the Medium of the Movement. http://content.time.com/time/world/article/0,8599,1905125,00.html, Access Date: 12.11.2017.

International Telecommunication Union (2017). Measuring the Information Society Report. Volume 1, Switzerland.

Iranonline (2017). Islamic Republic of Iran Constitution. http://www.iranonline.com/iran/iraninfo/government/constitution.html, Access Date: 15.12.2017.

Johnson, R. B., Onwuegbuzie, A. J., Turner, L. A. (2007). Toward a Definition of Mixed Methods Research. Journal of Mixed Methods Research, Vol 1, No 2, p. 112-133. 
Kamaladdin, N. (2017). Iran İslam Cumhuriyeti'nde Çatışma Ortamı Olarak Sanal Ortam. Yeni Medya Hakemli Akademik E-Dergi, Vol 2, p. 53-67.

Kashani, B. H., Kasmani, A. N., Sadipour, E., Soltanifar, M. (2017). Qualitative Study of Professionals' Perspectives about Internet Public Policy in Iran. International Journal of Computer Science and Network Security, Vol 17, No 8, p. 235-245.

Michaelsen, M. (2011). Linking up for Change: The Internet and Social Movements in Iran. N. C. Schneider and B. Gräf (Eds.). Social Dynamics 2.0: Researching Change in Times of Media Convergence: Case Studies from the Middle East and Asia (p. 105-126). Germany: Frank \& Timme. Mostafalou, Y., Adnan, H. M. (2016). Oppositional Politics and the Internet in Iran: A Visual Semiotic Analysis of the Iranian Green Path Movement's Website. Mediterranean Journal of Social Sciences, Vol 7, No 2, p. 113-126.

Rahimi, B. (2003). Cyberdissent: The Internet in Revolutionary Iran. Middle East Review of International Affairs, Vol 7, No 3, p. 101-115.

Tradingeconomics (2017). Iran Internet Speed. https://tradingeconomics.com/iran/internet-speed, Access Date: 19.09.2017.

Wearesocial (2017). Digital in 2017: Southern Asia. https://digitalinasia.com/2017/02/01/digital-inasia-2017-overview/, Access Date: 03.10.2017.

Worldbank (2016). Islamic Republic of Iran, Individuals Using the Internet. http://databank.worldbank.org/data/Views/Reports/ReportWidgetCustom.aspx?Report_Name=Countr $y$ Profile $\& I d=b 450 f d 57 \&$ tbar $=y \& d d=y \& i n f=n \& z m=n \&$ country $=I R N$, Access Date: $1 \overline{6} .12 .2017$. 